\title{
Additional Bibliography
}

Amores Conradi y Torralba Mendiola, Difamación y “Roma II”, AEDIPr 2007, 251

Bertrand Ancel, El reglamento «Roma II»: Apreciación de consunto, AEDIPr 2007, 607

Arenas García, La regulación de la responsabilidad precontractual en el reglamento "Roma II", AEDIPr 2007, 315

Ballarino, El derecho Antitrust Comunitario y el Art. 6 del reglamento “Roma II” (Régimen conflictual y territorial, efecto directo), AEDIPr 2007, 407

Bariatti, The Future Community Rules in the Framework of the Communitarization of Private International Law, in: Malatesta (ed.), The Unification of Choice of Law Rules on Torts and Other Non-Contractual Obligations in Europe (Padova 2006), p. 5

Basedow, Rome II at Sea: General Aspects of Maritime Torts: RabelsZ 74 (2010), 118 Beaumont, Private International Law of the European Union: Competence Questions Arising from the Proposed Rome II Regulation on Choice of Law in Non-Contractual Obligations, in: Ronald A. Brand (ed.), Private Law, Private International Law \& Judicial Cooperation in the EU-US Relationship (2005), p. 15

Beaumont/Tang, Classification of Delictual Damages - Harding v Wealands and the Rome II Regulation, (2008) 12 Edin. L.Rev. 135

Benecke, Auf dem Weg zu “Rom II”: der Vorschlag für eine Verordnung zur Angleichung des IPR der außervertraglichen Schuldverhältnisse, RIW 2003, 830

de Boer, Party Autonomy and its Limitations in the Rome II Regulation, YbPIL 9 (2007), 19

de Boer, De grindslagen van de Verordening Rome II, WPNR 6780 (2008), 988

de Boer, The Purpose of Uniform Choice-of-Law Rules: The Rome II Regulation, NIPR 2009, 295

Bogdan, General Aspects of the Future Regulation, in: Malatesta (ed.), The Unification of Choice of Law Rules on Torts and Other Non-Contractual Obligations in Europe (Padova 2006), p. 33

Boglione, Il Regolamento comunitario n. 864/2007 sulle regole di conflitto di legge applicable alle obbligazioni non contrattuali ("Roma II"), Assicurazioni 2009 I 571

Bona, Personal Injuries, Fatal Accidents and Rome II, in: Malatesta (ed.), The Unification of Choice of Law Rules on Torts and Other Non-Contractual Obligations in Europe (Padova 2006), p. 249

Boschiero, Infringement of Intellectual Property Rights. A Commentary on Article 8 of the Rome II Regulation, YbPIL 9 (2007), 87

Boskovic, Loi applicable aux obligations non contractuelles (matières civile et commercial), Rép. dr. eur. 26 (sept. 2010)

Bouček, Deliktni statut i nepošteno tržišno natjecanje u Uredbi Rim II, in: Liber amicorum Krešimir Sajko (Zagreb 2012), p. 17

Brière, Le règlement (CE) no 864/2007 du 11 juillet 2007 sur la loi applicable aux obligations non contractuelles (Rome II), Clunet 135 (2008), 31

Brière, Reflexions sur les interactions entre la proposition de reglement "Rome II" et les conventions internationales, Clunet 132 (2005), 677 


\section{Additional Bibliography}

Briggs, When in Rome, choose as the Romans do, (2009) 125 L.Q.Rev. 191

Buermeyer, Die Vereinheitlichung des Deliktskollisionsrechts in Europa durch die

Verordnung "Rom II", in: Liber amicorum Thomas Rauscher (2005), p. 15

Buonaiuti, Le obligazioni non contrattuali nel diritto internazionale privato (2013) van der Burg, De algemene verwijzingsregels van de nieuwe Rome II-verordening, SEW 2009, 374

Busse, Internationales Bereicherungsrecht zwischen EGBGB-Reform und "Rom II", RIW 2003, 406

Carballo Piñeiro, Derecho de competencia, intereses colectivos y su proyección procesal observaciones a propósito del Art. 6 del reglamento "Roma II", AEDIPr 2007, 465 Carella, The Law Applicable to Non-Contractual Obligations other than Tort or Delict, in: Malatesta (ed.), The Unification of Choice of Law Rules on Torts and Other NonContractual Obligations in Europe (Padova 2006), p. 73

Carella, La disciplina internazionalprivatistica delle obbligazioni da fatto lecito nella proposta di regolamento "Roma II", RDIPP 2005, 25

Carruthers/Crawford, Variations on a Theme of Rome II: Reflections on Proposed Choice of Law Rules for Non-Contractual Obligations, (2005) 9 Edin. L.Rev. 65 and 238

Chong, Choice of Law for Unjust Enrichment/Restitution and the Rome II Regulation, (2008) 56 ICLQ 1

Danov, Awarding exemplary (or punitive) antitrust damages in EC competition cases with an international element, [2008] Eur. Comp. L. Rev. 430

Dickinson, European Private International Law: Embracing New Horizons or Mourning the Past?, (2005) 1 JPrIL 197

Dickinson, Cross-Border Torts in EC Courts - A Repsonse to the Proposed "Rome II" Regulation, Eur. Bus. L. Rev. 13 (2002), 269

Dinwoodie, Conflicts and International Copyright Litigation: The Role of International Norms, in: Basedow/Drexl/Kur/Metzger (eds.), Intellectual Property in the Conflict of Laws (Tübingen 2005), p. 195

Dornis, When in Rome, Do as the Romans Do? A Defense of the Lex Domicilii Communis in the Rome II Regulation, EuLF 2007, I-152

Dornis, Contribution and Indemnification among Joint Tortfeasors in Multi-State Conflict Cases: A Study of Doctrine and Current Law in the US and Under the Rome II Regulation, (2008) 4 JPrIL 237 (2008)

Dorssemont/van Hoek, De collectieve actie bij arbeidsconflicten in Rome II, RDCB 2008, 515 Drexl, The Proposed Rome II Regulation: European Choice of Law in the Field of Intellectual Property, in: Drexl/Kur (eds.), Intellectual Property and Private International Law: Heading for the Future (Tübingen 2005), p. 151

Dutoit, Le droit international privé des obligations non contractuelles à l'heure européenne: le Règlement Rome II, in: Liber Fausto Pocar, vol. II (2009), p. 309

Editorial Comment, Sometimes it takes thirty years and even more ..., (2007) 44 C.M.L. Rev. 1567

Eichel, Die Anwendbarkeit von $\$ 287$ ZPO im Geltungsbereich der Rom I- und der Rom IIVerordnung, IPRax 2014, 156

Enneking, The common denominator of the Trafigura case, foreign direct liability cases and the Rome II Regulation, ERPL 2008, 283 
Espiniella Menéndez, Accidentes de circulación por carretera: del convenio de la haya de 4 de mayo de 1971 al reglamento (Ce) No 864/2007 ("Roma II"), AEDIPr 2007, 505

Fach Gómez, The Law Applicable to Cross-Border Environmental Damage: from the European National Systems to Rome II, YbPIL 6 (2004), 291

Fach Gómez, Propuesta de Reglamento del Paralamento Europeo y del Consejo relativo al la ley aplicable a las obligaciones extracontractuales ("Roma II"), in: Calvo Caravaca/Areal Ludeñas (dir.), Cuestiones actuales del Derecho mercantil internacional (2005), p. 3 Fallon, La Relación del reglamento "Roma II" con otras normas de conflicto de leyes, AEDIPr 2007, 187

Fallon, The Law Applicable to Specific Torts, in: Basedow/Baum/Nishitani (eds.), Japanese and European Private International Law in Comparative Perspective (Tübingen 2008), p. 261

Fallon, La relation du reglement Rome II avec d'autres regles de conflit de lois, RDCB 2008, 549

Francq, Le règlement "Rome II" concernant la loi applicable aux obligations non contractuelles - Entre droit communautaire et droit international privé, Rev. eur. dr. cons. 2007-2008, 319

Franzina, Il regolamento n. 864/2007/EC sulla legge applicabile alle obbligazioni extracontrattuali, NLCC 2008, 971

Franzina, Il Regolamento "Roma II" sulla legge applicabile alle obbligazioni extracontrattuali, in: Calvo Caravaca/Castellanos Ruiz (dir.), La Unión Europea ante el Derecho de la Globalización (2008), p. 299

Freitag, Rom I, Rom II - tertium est datur im Kollisionsrecht der Schuldverhältnisse!, in: FS Ulrich Spellenberg (2010), p. 169

Freitag, Die Rom-Verordnungen und die $\$ \$ 25-28$ HGB, ZHR 174 (2010), 429

Fresnedo de Aguirre/Fernandez Arroyo, A Quick Latin American Look at the Rome II Regulation, YbPIL 9 (2007), 193

Martin Fricke, Kollisionsrecht im Umbruch, VersR 2005, 726

Angelika Fuchs, Zum Kommissionsvorschlag einer “Rom II-Verordnung”, GPR 2003-2004, 100

Fuentes Mañas, La regla Lex Loci Delicti Commissi y normas localizadoras especiales en el reglamento "Roma II", AEDIPr 2007, 341

Garau Juaneda, La Conveniencia de una denuncia por parte de España del convenio de La Haya de 1971 sobre responsabilidad civil derivada de los accidentes de circulación, AEDIPr 2007, 497

Garcimartín Alférez, The Rome II Regulation: on the way towards a European Private International Law Code, EuLF 2007, I-77

Garcimartín Alférez, Un apunte sobre la llamada "Regla general" en el reglamento "Roma II", AEDIPr 2007, 241

Garcimartín Alférez, Hermeneutic Dialogue between Rome I and Rome II: General Principles and Argumentative Rules, in: Essays in Honour of Hans van Loon (2013), p. 169 Garofalo, Diritto comunitario e conflitti di leggi: spunti sulle nuove tendenze del diritto internazionale privato contemporaneo emergenti dal Regolamento Roma II, in: Liber Fausto Pocar, vol. II (2009), p. 413

Garriga, Relationship between Rome II and Other International Instruments. A Commentary on Article 28 of the Rome II Regulation, YbPIL 9 (2007), 137 


\section{Additional Bibliography}

George, Choice of Law in Maritime Torts, (2007) 3 JPrIL 137

Gil-Nievas, El proceso negociador del reglamento "Roma II": Obstáculos y resultados, AEDIPr 2007, 109

Grundmann, "Inter-Instrumental-Interpretation" - Systembildung durch Auslegung im Europäischen Unionsrecht, RabelsZ 75 (2011), 882

Guerchoun/Piedelievre, Le reglement sur la loi applicable aux obligations non contractuelles ("Rome II"), Gaz. Pal. 2007, 3106

Haftel, Entre "Rome II" et "Bruxelles I": L'interpretation communautaire uniforme du rrèglement "Rome I", Clunet 137 (2010), 761

Hahn/Tell, The European Commission's Agenda: The Future Rome I and Rome II Regulations, in: Basedow/Drexl/Kur/Metzger (eds.), Intellectual Property in the Conflict of Laws (Tübingen 2005), p. 7

Hamburg Group for Private International Law, Comments on the European Commission's Draft Proposal for a Council Regulation on the Law Applicable to Non-Contractual Obligations, RabelsZ 67 (2003), 1

Handig, Rom II-VO: Auswirkungen auf das Internationale Wettbewerbs- und Immaterialgüterrecht, wbl 2008, 1

Hartenstein, Rom I-Entwurf und Rom II-Verordnung: Zur Bedeutung zukünftiger Änderungen im Internationalen Privatrecht für das Seerecht, TranspR 2008, 143

Hartley, Choice of Law for Non-Contractual Liability: Selected Problems under the Rome II Regulation, (2008) 57 ICLQ 899

Hay, Contemporary Approaches to Non-Contractual Obligations in Private International Law (Conflict of Laws) and the European Community's "Rome II" Regulation, EuLF 2007, I137

von Hein, Die Kodifikation des europäischen Internationalen Deliktsrechts, ZvglRWiss 102 (2003), 528

von Hein, Die Kodifikation des europäischen IPR der außervertraglichen Schuldverhältnisse vor dem Abschluss?, VersR 2007, 440

von Hein, Die Ausweichklausel im europäischen Internationalen Deliktsrecht, in: FS Jan Kropholler (2008), p. 553

von Hein, Die internationale Prospekthaftung im Lichte der Rome II-Verordnung, in: Baum/Hellgardt/Fleckner/Markus Roth/Bliesener (eds.), Perspektiven des

Wirtschaftsrechts (2008), p. 371

von Hein, Something Old and Something Borrowed, but Nothing New? Rome II and the European Choice-of-Law Evolution, 82 Tul. L. Rev. 1663 (2008)

von Hein, Europäisches Internationales Deliktsrecht nach der Rom II-Verordnung, ZEuP 2009, 6

von Hein, Of Older Siblings and Distant Cousins: The Contribution of the Rome II

Regulation to the Communautarisation of Private International Law, RabelsZ 73 (2009), 461

von Hein, Finanzkrise und Internationales Privatrecht, BerDGesVR 45 (2012), 369

Heiss/Loacker, Die Vergemeinschaftung des Kollisionsrechts der außervertraglichen

Schuldverhältnisse durch Rom II, JBl 2007, 613

Michael Hellner, Unfair Competition and Acts Restricting Free Competition. A

Commentary on Article 6 of the Rome II Regulation, YbPIL 9 (2007), 49

Heredia Cervantes, Las deficiencias de la regla de responsabilidad múltiple del reglamento "Roma II", AEDIPr 2007, 277 
Hohloch, Place of Injury, Habitual Residence, Closer Connections and Substantive Scope the Basic Principles, YbPIL 9 (2007), 1

Honorati, The Law Applicable to Unfair Competition, in: Malatesta (ed.), The Unification of Choice of Law Rules on Torts and Other Non-Contractual Obligations in Europe (Padova 2006), p. 127

Honorati, Regolamento n. 864/2007 sulla legge applicabile alle obbligazioni non contrattuali, in: Preite/Gazzanti Pugliese di Cotrone (a cura di), Atti notarili - Diritto comunitario e internazionale, vol. I (Torino 2011), p. 483

Peter Huber/Bach, Die Rom II-VO: Kommissionsentwurf und aktuelle Entwicklung, IPRax 2005, 73

Peter Huber/Illmer, International Product Liability. A Commentary on Article 5 of the Rome II Regulation, YbPIL 9 (2007), 31

Iglesias Buhigues, El largo camino del reglamento “Roma II”, AEDIPr 2007, 97

Jiménez Blanco, El régimen de las acciones directas en el reglamento de Roma II, AEDIPr 2007, 287

Junker, Die Rom II-Verordnung: neues internationales Deliktsrecht auf europäischer Grundlage, NJW 2007, 3675

Junker, Das Internationale Privatrecht der Straßenverkehrsunfälle nach der Rom IIVerordnung, JZ 2008, 169

Junker, Der Reformbedarf im Internationalen Deliktsrecht der Rom II-Verordnung drei Jahre nach ihrer Verabschiedung, RIW 2010, 257

Junker, Kollisionsnorm und Sachrecht im IPR der unerlaubten Handlung, in: Liber amicorum Klaus Schurig (2012), p. 81

Kadner Graziano, The Law Applicable to Product Liability: The Present State of the Law in Europe and Current Proposals for Reform, (2005) 54 ICLQ 475

Kadner Graziano, The Law Applicable to Cross-Border Damage to the Environment. A Commentary on Article 7 of the Rome II Regulation, YbPIL 9 (2007), 71

Kadner Graziano, Le nouveau dorit international privé communautaire en matière de responsabilité extracontractuelle (règlement Rome II), RCDIP 97 (2008), 445

Kadner Graziano, The Rome II Regulation and the Hague Conventions on Traffic Accidents and Product Liability - Interaction, Conflicts and Future Perspectives, NIPR 2008, 425

Kadner Graziano, Das auf außervertragliche Schuldverhältnisse anzuwendende Recht nach Inkrafttreten der Rom II-Verordnung, RabelsZ 73 (2009), 1

Kellner, "Tort Law of the European Community": A Plea for an Overarching Pan-European Framework, ERPL 2009, 133

Kiesselbach, Financial Transaction in the Crossfire of Rome II, [2011] JIBFL 1

Knöfel, Internationales Arbeitskampfrecht nach der Rom II-Verordnung, EuZA 2008, 228

Bernhard Koch, Rom II ante portas - Ein Überblick über das neue europäische

Deliktskollisionsrecht, HAVE 2009, 17

Kono, Critical and Comparative Analysis of the Rome II regulation on Applicable Laws to Non-Contractual Obligations and the New Private International Law in Japan, in: Basedow/ Baum/Nishitani (eds.), Japanese and European Private International Law in Comparative Perspective (Tübingen 2008), p. 221

Koziol/Thiede, Kritische Bemerkungen zum derzeitigen Stand des Entwurfs einer Rom IIVerordnung, ZvglRWiss 106 (2007), 235 


\section{Additional Bibliography}

Kozyris, Rome II: Tort Conflicts on the Right Track! A Postscript to Symeon Symeonides' "Missed Opportunity", 56 Am. J. Comp. L. 471 (2008)

Xandra Ellen Kramer, The Rome II Regulation on the Law Applicable to Non-Contractual Obligations: The European Priavte International law Tradition Continued - Introductory Observations, Scope, System and General Rules, NIPR 2008, 414

Kreuzer, Die Vergemeinschaftung des Kollisionsrechts für außervertragliche Schuldverhältnisse (Rom II), in: Reichelt/Rechberger (eds.), Europäisches Kollisionsrecht (Wien 2004), p. 13

Kreuzer, Tort Liability in General, in: Malatesta (ed.), The Unification of Choice of Law Rules on Torts and Other Non-Contractual Obligations in Europe (Padova 2006), p. 45 Kur, Trademark Conflicts on the Internet: Territoriality Redefined?, in: Basedow/Drexl/ Kur/Metzger (eds.), Intellectual Property in the Conflict of Laws (Tübingen 2005), p. 175

Landbrecht, Rechtswahl ex ante und das Deliktsstatut nach dem europäischen Kollisionsrecht (Rom I und Rom II), RIW 2010, 783

Légier, Le règlement "Rome II" sur la loi applicable aux obligations non contractuelles, JCP G 2007 I.207 = JCP G N 47, 21 novembre 2007, p. 13

Matthias Lehmann, Where Does Economic Loss Occur?, (2011) 6 JPrIL 527

Matthias Lehmann, Vorschlag für eine Rom II-Verordnung im Bereich der Finanzmarktdelikte, IPRax 2012, 399

Matthias Lehmann, Proposition d'une règle special dans le Règlement Rome II pour les délits financiers, RCDIP 101 (2012), 485

Matthias Lehmann/Duczek, Grundfälle zur Rom II-VO, JuS 2012, 681 and 788

Leible, Der Beitrag der Rom II-Verordnung zu einer Kodifikation der allgemeinen Grundsätze des Europäischen Kollisionsrechts, in: Reichelt (Hrsg.), Europäisches Gemeinschaftsrecht und IPR (Wien 2007), p. 31

Leible, El alcance de la autonomía de la voluntad en la determinación de la ley aplicable a las obligaciones contractuales en el reglamento, AEDIPr 2007, 187

Leible, Rechtswahl im IPR der außervertraglichen Schuldverhältnisse nach der Rom IIVerordnung, RIW 2008, 257

Leible/Andreas Engel, Der Vorschlag der EG-Kommission für eine Rom-II Verordnung, EuZW 2004, 7

Leible/Matthias Lehmann, Die neue EG-Verordnung über das auf außervertragliche Schuldverhältnisse anzuwendende Recht ('Rom II'), RIW 2007, 721

Lein, The New Rome I/Rome II/Brussels I Synergy, YbPIL 10 (2008), 177

Leistner, Comments: The Rome II Regulation Proposal and its Relation to the European Country-of-Origin Principle, in: Drexl/Kur (eds.), Intellectual Property and Private International Law: Heading for the Future (Tübingen 2005), p. 177

de Lima Pinheiro, Choice of Law on Non-Contractual Obligations between Communitarization and Globalization: a first Assessment of EC Regulation Rome II, RDIPP 2008, 5

Lüttringhaus, Das internationale Privatrecht der culpa in contrahendo nach den EGVerordnungen "Rom I" und "Rom II", RIW 2008, 193

Lüttringhaus, Übergreifende Begrifflichkeiten im europäischen Zivilverfahrens- und Kollisionsrecht, RabelsZ 77 (2013), 31

Malatesta, The Law Applicable to Traffic Accidents, in: Malatesta (ed.), The Unification of 
Choice of Law Rules on Torts and Other Non-Contractual Obligations in Europe (Padova 2006), p. 85

Mankowski, Ausgewählte Einzelfragen zur Rom II-VO: Internationales

Umwelthaftungsrecht, Internationales Kartellrecht, renvoi, Parteiautonomie: IPRax 2010, 389

Mankowski, Das neue Internationale Kartellrecht des Art 6 Abs. 3 der Rom II-Verordnung, RIW 2008, 177

Marenghi, La legge applicabile al danno da prodotto nell'Unione Europea: l'art. 5 del Regolamento n. 854/2007/CE, Dir. comm. int. 25 (2011), 335

Mari, La subrogación en el reglamento (CE) No 864/2007: Aspectos problemáticos, AEDIPr 2007, 267

Martiny, Zur Einordnung und Anknüpfung der Ansprüche und der Haftung Dritter im Internationalen Schuldrecht, in: FS Ulrich Magnus (2014), p. 483

Meeusen, Rome II: nieuw Europees conflictenrecht voor niet-contractuele verbintenissen, RDCB 2008, 471

Metzger, Community Rights \& Conflict of Laws: Community Trademark, Community Design, Community Patent - Applicable Law for Claims of Damages, in: Drexl/Kur (eds.), Intellectual Property and Private International Law: Heading for the Future (Tübingen 2005), p. 215

De Miguel Asensio, La Lex Loci Protectionis tras el reglamento “Roma II”, AEDIPr 2007, 375

De Miguel Asensio, El régimen comunitario relativo a la le aplicable a las obligaicones extracontractuales, Rev. esp. seguros 2009, 695

Mortensen, A Common Law Cocoon: Australia and the Rome II Regulation, YbPIL 9 (2007), 203

Muir Watt, Rome II et les "interêts gouvernementaux": pour une lecture functionnaliste du nouveau règelment du conflit de lois en matière delictuelle, in: Corneloup/Joubert (dir.), Le règlement communautaire dit 'Rome II' sur la loi applicable aux obligations non contractuelles (2008) p. 129

Munari/Schiano di Pepe, Liability for Environmental Torts in Europe, in: Malatesta (ed.), The Unification of Choice of Law Rules on Torts and Other Non-Contractual Obligations in Europe (Padova 2006), p. 173

Nishitani, The Rome II Regulation from a Japanese Point of View, YbPIL 9 (2007), 175

Nourissat/Treppoz, Quelques observations sur l'avant-projet de proposition de règlement du Conseil sur la loi applicable aux obligations non contractuelles, Clunet 130 (2003), 7

Nugel, Führen alle Wege nach "Rom II"?, NJW-Spezial 2010, 9

Nuyts, La règle générale de conflit de lois en matiere non contractuelle dans le Règlement Rome II, RDCB 2008, 489

Ofner, Die Rom II-Verordnung: neues Internationales Privatrecht für außervertragliche Schuldverhältnisse in der Europäischen Union, ZfRV 2008, 13

Othenin-Girard, Règlement Rome II et LDIP: quelques points de convergence et de divergence, SJZ 2009, 381

Palao Moreno, The Law Applicable to a Non-Contractual Obligation with Respect to an Industrial Action. A Commentary on Article 9 of the Rome II Regulation, YbPIL 9 (2007), 115 


\section{Additional Bibliography}

David Paulus, Außervertragliche Gesellschafter- und Organwalterhaftung im Lichte des Unionskollisionsrechts (2013)

Pertegás Sender, Patent Infringement: Choice of Laws, and the Forthcoming Rome II Regulation, in: Basedow/Drexl/Kur/Metzger (eds.), Intellectual Property in the Conflict of Laws (2005), p. 159

Pertegás Sender, Intellectual Property and Choice of Law Rules, in: Die (ed.), The Unification of Choice of Law Rules on Torts and Other Non-Contractual Obligations in Europe (Padova 2006), p. 221

Petch, The Rome II Regulation: An Update, [2006] JIBLR 449 and 509

Pfeiffer, Datumtheorie und "local data" in der Rom II-VO - am Beispiel von

Straßenverkehrsunfällen, in: Liber amicorum Klaus Schurig (2012), p. 229

Pironon, L'entrée du droit de la concurrence dans le reglement 'Rome II': bonne ou mauvaise idee?, Europe 18 (2008), 6

Pontier, Rome II: Geen revolutionaire omwentelingen, veltal van vraagpunten bij de inwerkingtreden efvan, MedNVIR 136 (2008), 61

Posch, The "Draft Regulation Rome II" in 2004: Its Past and Future Perspectives, YbPIL 6 (2004), 129

Rodríguez Pineau, Ley aplicable a la responsabilidad derivada de actos contrarios a la libre competencia, AEDIPr 2007, 447

Wulf-Henning Roth, Internationales Kartelldeliktsrecht in der Rom II-Verordnung, in: FS Jan Kropholler (2008), p. 623

Claudia Rudolf, Europäisches Kollisionsrecht für außervertragliche Schuldverhältnisse Rom II-VO; ÖJZ 2010, 300

Rugullis, Die antizipierte Rechtswahl in außervertraglichen Schuldverhältnissen, IPRax 2008, 319

Rushworth, Remedies and the Rome II Regulation, in: Ahern/Binchy (eds.), The Rome II Regulation on the Law Applicable to Non-Contractual Obligations (2009), p. 199

Rushworth/Andrew Scott, Choice of law for non-contractual obligations, [2008] LMCLQ 274

Saravalle, The Law Applicable to Products Liability: Hopping Off the Endless Merry-GoRound, in: Malatesta (ed.), The Unification of Choice of Law Rules on Torts and Other NonContractual Obligations in Europe (Padova 2006), p. 107

Schack, Das auf (formlose) Immaterialgüterrechte anwendbare Recht nach Rom II, in: FS Jan Kropholler (2008), p. 651

Schaper, Choice-of-Law Rules in the EU: Special Issues with Respect to Community Rights Infringement of Community Trade Marks and Applicable Law in: Drexl/Kur (eds.), Intellectual Property and Private International Law: Heading for the Future (Tübingen 2005), p. 201

Renate Schaub, Streuschäden im deutschen und europäischen Recht, JZ 2011, 13

Schilf, Römische IPR-Verordnungen - Kein Korsett für europäische Schiedsgerichte, RIW 2013, 678

Jessica Schmidt, Grundlagen des europäischen Internationalen Privatrechts, Jura 2011, 117 Schoeman, Rome II and the substance-procedure dichotomy: crossing the Rubicon, [2010] LMLCQ 81

Schwander, Überlegungen zur Rom II-Verordnung aus der Sicht des schweizerischen internationalen Privatrechts, HAVE 2009, 63 
Siehr, Geldwäsche im IPR - Ein Anknüpfungssystem für Vermögensdelikte nach der Rom II-VO, IPRax 2009, 435

Siehr, The Rome II Regulation and Specific Maritime Torts: Product Liability,

Environmental Damage, Industrial Action, RabelsZ 74 (2010), 139

Siems, Die Harmonisierung des Internationalen Deliktsrechts und die "Einheit der

Rechtsordnung", RIW 2004, 262

Sonnentag, Zur Europäisierung des Internationalen außervertraglichen Schuldrechts durch die geplante Rom II-Verordnung, ZvglRWiss 105 (2006), 256

Spickhoff, Die Produkthaftung im Europäischen Kollisions- und Zivilverfahrensrecht, in: FS Jan Kropholler (2008), p. 671

Spickhoff, Die Arzthaftung im Europäischen Internationalen Privat- und Prozessrecht, in: FS Gerda Müller (2009), p. 287

Ansgar Staudinger, Rome II and Traffic Accidents, EuLF 2005, I-61

Ansgar Staudinger, Rechtsvereinheitlichung innerhalb Europas: Rom I und Rom II, AnwBl 2008, 8

Ansgar Staudinger, Das Konkurrenzverhältnis zwischen dem Haager

Straßenverkehrsübereinkommen und der Rom II-VO, in: FS Jan Kropholler (2008), p. 691

Ansgar Staudinger/Steinrötter, Die Rom-Verordnungen, JA 2011, 241

Stoll, Zur Flexibilisierung des europäischen internationalen Deliktsrechts: Vermittelnde

Kritik aus Amerika an der Rom II-VO, in: FS Rudolf Reischauer (Wien 2010), p. 389

Stone, The Rome II Proposal on the Law Applicable to Non-Contractual Obligations, EuLF 2004, I-213

Stone, The Rome II Regulation on Choice of Law in Tort, (2007) 4 Ankara L. Rev. 95

Strikwerda, Van 'lex loci delicti' naar 'lex loci damni', WPNR 6780 (2008), 993

Sujecki, Die Rom II-Verordnung, EWS 2009, 310

Symeonides, Rome II and Tort Conflicts: A Missed Opportunity, 56 Am. J. Comp. L. 173

(2008)

Symeonides, Rome II - A Centrist Critique, YbPIL 9 (2007), 149

Symeonides, Tort Conflicts and RomeII: A View from Across, in: FS Erik Jayme (2004), p. 935

Thiede, "Forum shopping" zwischen dem Haager Übereinkommen über das auf

Verkehrsunfälle anzuwendende Recht und der Rom-II-Verordnung - Eine Fallstudie, VersR 2007, 1624-1627

Thiede, EU Conflict of Laws, in: Oliphant/Steininger (eds.), European Tort Law (Wien 2011), p. 293

Thiede/Kellner, "Forum shopping" zwischen dem Haager Übereinkommen über das auf Verkehrsunfälle anzuwendende Recht und der Rom-II-Verordnung?, VersR 2007, 1624 Thiede/Ludwichowska, Die Haftung bei grenzüberschreitenden unerlaubten Handlungen, ZVglRWiss 106 (2007), 92

Tilmann, Community IP Rights and Conflict of Laws, in: Basedow/Drexl/Kur/Metzger (eds.), Intellectual Property in the Conflict of Laws (Tübingen 2005), p. 123

Trüten, Europäische Kollisionsrechtsvereinheitlichung am Beispiel der "Rom II-

Verordnung”, EuZ 2008, 82

de Vareilles-Sommieres, La responsabilité civile dans la proposition de reglement communautaire sur la loi applicable aux obligations non contractuelles (Rome II), in: Angelika Fuchs/Muir-Watt/Pataut (eds.), Les conflits de lois et le systeme juridique communautaire (2004), p. 185 


\section{Additional Bibliography}

Vitellino, Rome II from an Internal Market Perspective, in: Malatesta (ed.), The Unification of Choice of Law Rules on Torts and Other Non-Contractual Obligations in Europe (Padova 2006), p. 271

Vogeler, Die freie Rechtswahl im Kollisionsrecht der außervertraglichen Schuldverhältnisse (2013)

Volders, Culpa in Contrahendo in the Conflict of Laws. A Commentary on Article 12 of the Rome II Regulation, YbPIL 9 (2007), 127

Volders, Niet-contractuele verbintenissen en Rome II, RDCB 2008, 482

Volders, Communautair verwijzingsrecht voor niet-contractuele verbintenissen, R.W. 201011,1154

Wadlow, Trade secrets and the Rome II Regulation on the law applicable to non-contractual obligations, [2006] EIPR 309

Gerhard Wagner, Internationales Deliktsrecht, die Arbeiten an der Rom II-Verordnung und dem europäischen Deliktsgerichtsstand, IPRax 2006, 372

Gerhard Wagner, Die neue Rom-II Verordnung, IPRax 2008, 1

Rolf Wagner, Ein neuer Anlauf zur Vereinheitlichung des IPR für außervertragliche Schuldverhältnisse auf EU-Ebene, EuZW 1999, 709

Rolf Wagner, Änderungsbedarf im autonomen deutschen Internationalen Privatrecht aufgrund der Rom II-Verordnung?, IPRax 2008, 314

Rolf Wagner, Das Vermittlungsverfahren der Rom II-Verordnung, in: FS Jan Kropholler (2008), p. 715

Wallis, Introduction: Rome II - A Parliamentary Tale, in: Ahern/Binchy (eds.), The Rome II Regulation on the Law Applicable to Non-Contractual Obligations (2009), p. 1

Warshaw, Uncertainty from Abroad: Rome II and the Choice of Law for Defamation Claims, 32 Brooklyn J. Int'l. L. 269 (2006)

van der Weide, Europees internationaal privaatrecht - Het verwijzingsrecht voor nietcontractuele verbintenissen Europees geregeld. Een analyse van de verordening Rome II, NTER 2008, 214

Weintraub, Rome II and the Tension between Predictability and Flexibility, in: Liber Amoricum Peter Hay (2005), p. 451

Weintraub, The Choice of Law Rules of the European Community Regulation on the Law Applicable to Non-Contractual Obligations: Simple and Predictable, Consequences-Based, or Neither?, 43 Texas Int'l. L.J. 401 (2008)

Wilderspin, The Rome II Regulation - Some Policy Considerations, NIPR 2008, 408 Markus Würdinger, Das Prinzip der Einheit der Schuldrechtsverordnungen im europäischen Internationalen Privat- und Verfahrensrecht, RabelsZ 75 (2011), 102

Zambrana, Derecho internacional, derechos humanos y reponsabilidad extracontractual, AEDIPr 2007, 579

Zhang, Party Autonomy in Non-Contractual Obligations: Rome II and Its Impact on Choice of Law, 39 Seton Hall. L. Rev. 861 (2009). 